Original Article

\title{
Evaluation of the Effect of Mefenamic Acid Alone and Combination with Fennel (Foenicullum Vulgare) on Primary Dysmenorrhoea \\ ${ }^{*}$ Nesa $\mathrm{K}^{1}$, Iqbal MJ ${ }^{2}$, Halim $\mathrm{KS}^{3}$, Jahan $\mathrm{J}^{4}$
}

\begin{abstract}
Primary dysmenorrhea refers to painful menstrual cramps of uterus led to considered gynecological complaint. Menstrual discomfort was reported in half to four-fifth of females and one-fourth reported sever dysmenorrhea. Newer combination of herbal products like Fennel and Mefenamic acid becoming popular and replacing conventional NSAIDs/ OCPs therapy for their major adverse effect. The aim of this study was to compare the effect of Mefenamic acid alone and combination with Fennel (Foenicullum Vulgare) on primary dysmenorrhoea. This interventional study was conducted among randomly selected 100 female workers with age range 18-25 years of two Garments Factories at Demra, Dhaka during July 2014 to June with the complaints of moderate to severe pain intensity and bleeding of primary dysmenorrhea. There were two group, group $A$ (50 women) were treated with Cap Mefenamic Acid $250 \mathrm{mg}$ once daily and group B (50) were with Cap Mefenamic Acid $250 \mathrm{mg}$ once daily and fennel supplementation $10 \mathrm{ml}$ three times daily. The mean age of respondents was $21.60 \pm 2.59$ and menarche age was $13.92 \pm 1.15$ year. Mean duration of the menstrual cycle and cycle length were $6.24 \pm 1.66$ and $27.36 \pm 3.63$ days

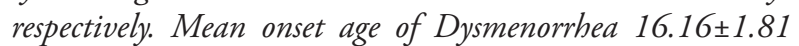
year and intensity of dysmenorrhea (VAS-Visual Analogue Scale) 6.5 \pm 1.6. Group $A$ had no any special experience on pain reliefsensation by taking Mefenamic Acid alone, whereas Group $B$ gathered better experience after administration of
\end{abstract}

1. *Dr. Kamrun Nesa, Assistant Professor, Department of Pharmacology, Shahabuddin Medical College and Hospital.

Email:kamrunnesa46@gmail.com, Cell Ph. 01777811170

2. Dr. Md. Jalaluddin Iqbal, Associate Professor, Department of Pharmacology \& Therapeutics, Sir Salimullah Medical College, Bangladesh.

3. Dr. Kazi Shafiqul Halim, Professor, Department of Epidemiology, National Institute of Preventive and Social Medicine (NIPSOM), Mohakhali, Dhaka.

4. Dr. Israt Jahan, Assistant Professor, Department of Pharmacology, MH Samorita Hospital and Medical College.

*For correspondence
Cap Mefenamic Acid with fennel supplementation. Moreover, according to result of the analysis, comparison with bleeding tendency was also not shown the significant difference. One more important thing is that these two group faced some adverse effect of those medication such as group $A$ had no complaints of allergic reaction, visual and neurologic disturbance where 2\% had gastro-intestinal upset and 2\% had respiratory distress in Group A; on the other hand, 2\% had allergic reaction, $2 \%$ had visual symptom and respiratory distress had $4 \%$ cases in Group B. Mefenamic acid with fennel can decrease the severity of dysmenorrhea. However, any intervention might be found out to treat dysmenorrhea with less adverse effects is highly desired.

Keywords: Primary dysmenorrhoea, Effect of mefenamic acid, Fennel supplementation, Foenicullum vulgare, Herbal product.

\section{INTRODUCTION}

Dysmenorrhea is a common menstrual complaint with major impact on women's quality of life, work productivity, health care utilization. Primary dysmenorrhoea is defined as painful menstruation in women with normal pelvic condition, usually begins in teenage girls. It is characterized by cramping pelvic pain beginning prior to or at the onset of menstruation and lasting up to three days. Dysmenorrhoea sometimes may be secondary to the pathological condition of pelvic organ.

The prevalence is difficult to determine because of different definitions of the condition- prevalence estimates vary from $45 \%$ to $95 \%$. However, dysmenorrhoea seems to be the most common gynaecological condition in women regardless of age and nationality. ${ }^{1}$

A multidisciplinary approach involving a combination of life style, medications, and allied health services should be used to limit the impact of this condition on activities of daily living. In some circumstances surgery is required to offer the desired relief. ${ }^{2}$ Treatments such as Paracetamol, aspirin, and non-steroidal anti-inflammatory drugs (NSAIDS) work by reducing the activity of cyclooxygenase pathways, thus inhibiting prostaglandins production. ${ }^{3}$ 
NSAIDS (Non-Steroidal Anti-Inflammatory Drug) are the best established initial therapy for dysmenorrheal. ${ }^{4}$ Primary dysmenorrhea refers to the occurrence of painful menstrual cramps of uterus and is considered as a gynecological complaint. On the contrary, the herbal products such as Fennel (Foeniculum vulgare) Garlic (Allium sativum), Ginger (zingiber offinale), Cinanamon (Cinnamon cassia) are now becoming popular to their anti dysmenorric property. The dosage of Mefenamic Acid is from $500 \mathrm{mg}$ to a maximum dose and frequency should be adjusted to suit an individual patient's need. For the relief of acute pain in adults and adolescents 14 yrs. of age, the recommendation dose is $500 \mathrm{mg}$ as initial dose followed by $250 \mathrm{mg}$ every 6 hourly as needed usually not to exceed one week. ${ }^{5}$ The prevalence of dysmenorrhea has been differently reported between 30 and $85 \%$. Louder milk expressed prevalence of dysmenorrhea between 50 and $80 \%$ with 10 to $18 \%$ of people having severe dysmenorrhea. ${ }^{6}$

There are some characters of Fennel, such as menstrual disorders: Fennel is also an Emenagogue, meaning that it eases and regulates menstruation by properly regulating hormonal action in the body. Furthermore, fennel is used in a number of products to reduce the effects of PMS, and it is also used traditionally as a soothing pain reliever and relaxing agent for menopausal women. Anti-spasmodic effect: The antispasmodic, phytoestrogen and antiinflammatory properties of Fennel may soothe the muscles in the uterus, which can help relieve the cramping and discomfort associated with PMS and menstruation. Fennel can also help ease hot flashes and other menopausal problems by balancing the estrogen levels in the body. Therefore, a simple remedy for menstrual cramps, PMS, and symptoms of menopause. Fennel is an antispasmodic and anethol agents. For centuries, fennel fruits (F. vulgare) have been used as traditional herbal medicine in Europe and China. ${ }^{3}$

Fennel seeds were one of the acceptable herbal drugs of primary dysmenorrhea in Iran. F. vulgare is helpful in colic and has a slight pain reducing potentiality in dysmenorrhea. Many studies recommended more studies about fennel in primary dysmenorrheal ${ }^{7}$.

\section{RESULT}

The baseline characteristics of the respondents, the mean of age (year) $21.60 \pm 2.59$, Menarche age (year) 13.92 \pm 1.15 , Duration of the menstrual cycle (Day) 6.24 \pm 1.66 , Duration of the cycle length (Day) 27.36 \pm 3.63 , Onset age of Dysmenorrhoea (year) 16.16 \pm 1.81 , intensity of dysmenorrhoea (VAS) 6.5 \pm 1.6

In Group A (Mefenamic acid) and mean age (year) $22.20 \pm 3.72$, Menarche age (year) $13.17 \pm 2.23$, Duration of the menstrual cycle (Day) 6.17 \pm 1.41 , Duration of the cycle length (Day) 27.03 \pm 3.81 , Onset age of Dysmenorrhoea (Year) 15.50 \pm 2.71 , Intensity of dysmenorrhoea (VAS) $6.6 \pm 1.4$

Table 1: Baseline characteristics of the participants $(n=100)$

\begin{tabular}{|l|c|c|c|c|l|}
\hline Characteristics & $\begin{array}{c}\text { Group-A } \\
(\mathbf{n = 5 0}) \\
\text { Mean } \pm \text { SD }\end{array}$ & $\begin{array}{c}\text { Group-B } \\
(\mathbf{n}=\mathbf{5 0}) \\
\text { Mean } \pm \text { SD }\end{array}$ & Min. & Max. & p-value \\
\hline Age (year) & $21.60 \pm 2.59$ & $22.20 \pm 3.72$ & 18 & 30 & $0.35^{\text {ns }}$ \\
\hline Menarche age (year) & $13.92 \pm 2.15$ & $13.17 \pm 2.23$ & 10 & 16 & $0.09^{\text {ns }}$ \\
\hline Duration of the menstrual cycle (Day) & $6.24 \pm 1.66$ & $6.17 \pm 1.41$ & 4 & 9 & $0.82^{\text {ns }}$ \\
\hline Duration of the cycle length (Day) & $27.36 \pm 3.63$ & $27.03 \pm 3.81$ & 25 & 32 & $0.65^{\text {ns }}$ \\
\hline Onset age of Dysmenorrhoea (Year) & $16.16 \pm 1.81$ & $15.50 \pm 2.71$ & 11 & 19 & $0.16^{\text {ns }}$ \\
\hline Intensity of Dysmenorrhoea (VAS) & $6.5 \pm 1.6$ & $6.6 \pm 1.4$ & 3.5 & 9 & $0.74^{\text {ns }}$ \\
\hline
\end{tabular}

$\mathrm{n}=$ Number of subjects; ${ }^{*}=$ Significant; $\mathrm{ns}=$ Not significant

The test of significance was calculated and $\mathrm{p}$ values $<0.05$ was accepted as level of significance.

Group-A: Mefenamic acid

Group-B: Mefenamic acid with fennel 
In Group B (Mefenamic acid with fennel). All the baseline characteristics. There is no statistically significant difference between two groups in baseline data.

The pain intensity before and after drug in menses $1^{\text {st }}$ to $5^{\text {th }}$ day in Group A. The mean intensity of pain in the mefenamic acid group decreased from $3.26 \pm 0.83$, $2.55 \pm 0.50,2.30 \pm 0.60,1.55 \pm 0.73$ before drug down to $2.02 \pm 0.66,1.95 \pm 0.66,1.80 \pm 0.71,1.10 \pm 0.060 .31 \pm 0.06$ in after drug in the day of menstrual period, $1^{\text {st }}$ day, $2^{\text {nd }}$ day, $3^{\text {rd }}$ day, $4^{\text {th }}$ day and $5^{\text {th }}$ day respectively. The difference of pain intensity before and after use of drug were statistically significant.

\section{Table II: Comparison of Pain Intensity in the Mefenamic Acid Group before and after Intervention $(\mathbf{n}=50)$}

\begin{tabular}{|l|c|c|c|}
\hline $\begin{array}{l}\text { Day of } \\
\text { Menstruation }\end{array}$ & $\begin{array}{c}\text { Pain intensity } \\
\text { before drug } \\
(\mathbf{n}=50) \\
\text { Mean } \pm \text { SD }\end{array}$ & $\begin{array}{c}\text { Pain intensity } \\
\text { after drug } \\
(\mathbf{n}=50) \\
\text { Mean } \pm \text { SD }\end{array}$ & $\begin{array}{c}\text { p- } \\
\text { Value }\end{array}$ \\
\hline $1^{\text {st }}$ day & $3.26 \pm 0.83$ & $2.02 \pm 0.77$ & $<0.001^{*}$ \\
\hline $2^{\text {nd }}$ day & $2.55 \pm 0.50$ & $1.95 \pm 0.66$ & $<0.001^{*}$ \\
\hline $3^{\text {rd }}$ day & $2.35 \pm 0.60$ & $1.80 \pm 0.71$ & $0.003^{*}$ \\
\hline $4^{\text {th }}$ day & $1.55 \pm 0.73$ & $1.10 \pm 0.71$ & $0.039^{*}$ \\
\hline $5^{\text {th }}$ day & $1.55 \pm 0.31$ & $0.31 \pm 0.06$ & $0.027^{*}$ \\
\hline
\end{tabular}

Results are expressed as Mean $\pm \mathrm{SD}$.

Paired sample ' $\mathrm{t}$ ' test was performed to compare between groups.

$\mathrm{n}=$ Number of subjects; ${ }^{*}=$ Significant;

$\mathrm{ns}=$ Not significant

The test of significance was calculated and

$\mathrm{p}$ values $<0.05$ was accepted as level of significance.

Group-A: Mefenamic acid

Group-B: Mefenamic acid with fennel

The pain intensity before and after drug in menses $1^{\text {st }}$ to $5^{\text {th }}$ day in Group B. The mean intensity of pain in the mefenamic acid with fennel group decreased from $3.4 \pm 0.88,2.6 \pm 0.50,2.4 \pm 0.58,1.6 \pm 0.60$ and $0.6 \pm 0.59$ before drug down to $2.0 \pm 0.74,1.9 \pm 0.67,1.7 \pm 0.62$, $1.0 \pm 0.50$ and $0.2 \pm 0.70$ in after drug in the day of menstrual period, $1^{\text {st }}$ day, $2^{\text {nd }}$ day, $3^{\text {rd }}$ day, $4^{\text {th }}$ day and $5^{\text {th }}$ day respectively. The difference of pain intensity before and after use of drug were statistically significant.
Table III: Comparison of pain intensity in the Mefenamic Acid with fennel group B before and after intervention $(n=50)$

\begin{tabular}{|l|c|c|c|}
\hline $\begin{array}{l}\text { Day of } \\
\text { Menstruation }\end{array}$ & $\begin{array}{c}\text { Pain intensity } \\
\text { before drug } \\
(\mathbf{n}=50) \\
\text { Mean } \pm \text { SD }\end{array}$ & $\begin{array}{c}\text { Pain intensity } \\
\text { after drug } \\
(\mathbf{n}=50) \\
\text { Mean } \pm \text { SD }\end{array}$ & $\begin{array}{c}\text { p- } \\
\text { Value }\end{array}$ \\
\hline $1^{\text {st }}$ day & $3.4 \pm 0.88$ & $2.0 \pm 0.74$ & $<0.001^{*}$ \\
\hline $2^{\text {nd }}$ day & $2.6 \pm 0.50$ & $1.9 \pm 0.67$ & $<0.001^{*}$ \\
\hline $3^{\text {rd }}$ day & $2.4 \pm 0.58$ & $1.7 \pm 0.62$ & $<0.001^{*}$ \\
\hline $4^{\text {th }}$ day & $1.6 \pm 0.60$ & $1.0 \pm 0.50$ & $<0.001^{*}$ \\
\hline $5^{\text {th }}$ day & $0.6 \pm 0.59$ & $0.2 \pm 0.70$ & $0.002^{*}$ \\
\hline
\end{tabular}

Results are expressed as Mean $\pm \mathrm{SD}$.

Paired sample ' $t$ ' test was performed to compare between groups.

$\mathrm{n}=$ Number of subjects; ${ }^{*}=$ Significant;

$\mathrm{ns}=$ Not significant

The test of significance was calculated and $\mathrm{p}$ values $<0.05$

was accepted as level of significance.

Group-A: Mefenamic acid

Group-B: Mefenamic acid with fennel

The menstrual bleeding severity (cycles 0,1 and 2) in the two study groups, paired t-test used to compare bleeding severity in the two groups. According to the results of the analysis, there was significant difference in bleeding severity in the Group A and Group B in zero to cycle 2 if menstrual bleeding.

Table IV: Mean and standard deviation of menstrual bleeding severity (cycles 0,1 and 2) in the two study groups $(\mathbf{n}=50)$

\begin{tabular}{|c|c|c|}
\hline $\begin{array}{l}\text { Menstrual } \\
\text { bleeding }\end{array}$ & $\begin{array}{c}\text { Mefenamic } \\
\text { acid }(n=50) \\
\text { Mean } \pm \text { SD }\end{array}$ & $\begin{array}{c}\text { Fennel with } \\
\text { mefenamic } \\
\text { acid }(n=50) \\
\text { Mean } \pm S D\end{array}$ \\
\hline Cycle 0 (without drug) & $31.1 \pm 3.1$ & $21.2 \pm 3.2$ \\
\hline Cycle 1 (with drug) & $16.2 \pm 4.7$ & $11.2 \pm 4.9$ \\
\hline Cycle 2 (With drug) & $22.4 \pm 5.1$ & $10.4 \pm 5.6$ \\
\hline $\begin{array}{l}\text { Statistical analysis } \\
\text { Cycle } 0 \text { (without drug) } \\
\text { vs }\end{array}$ & & \\
\hline $\begin{array}{l}\text { Cycle } 1 \text { (with drug) } \\
\text { Cycle } 0 \text { (without drug) } \\
\text { vs }\end{array}$ & $<0.001^{*}$ & $<0.001^{*}$ \\
\hline Cycle 2 (with drug) & $<0.001^{*}$ & $<0.001^{*}$ \\
\hline
\end{tabular}


The test of significance was calculated and $\mathrm{p}$ values $<0.05$ was accepted as level of significance.

The menstrual pain severity (cycles 0,1 and 2) in the two study groups, paired t-test used to compare bleeding severity in the two groups. According to the results of the analysis, there was significant difference in pain severity in the Group $A$ and Group B in zero to cycle 2 in menstrual pain severity.

\section{Table V: Mean and standard deviation of menstrual pain severity (cycles 0,1 and 2 ) in the two study groups $(\mathrm{n}=50)$}

\begin{tabular}{|l|c|c|}
\hline Menstrual Cycle & $\begin{array}{c}\text { Mefenamic } \\
\text { Acid }(\mathbf{n}=50) \\
\text { Mean } \pm \text { SD }\end{array}$ & $\begin{array}{c}\text { Fennel with } \\
\text { Mefenamic Acid } \\
(\mathbf{n}=50) \\
\text { Mean } \pm \text { SD }\end{array}$ \\
\hline Cycle 0 (without drug) & $5.6 \pm 1.9$ & $5.8 \pm 1.5$ \\
\hline Cycle 1 (with drug) & $4.1 \pm 0.8$ & $4.2 \pm 1.3$ \\
\hline Cycle 2 (with drug) & $3.6 \pm 1.7$ & $3.2 \pm 1.7$ \\
\hline Statistical analysis & & \\
\hline $\begin{array}{l}\text { Cycle 0 (without drug) } \\
\text { vs } \\
\text { Cycle 1 (with drug) }\end{array}$ & $<0.001^{*}$ & $<0.001^{*}$ \\
\hline $\begin{array}{l}\text { Cycle 0 (without drug) } \\
\text { vs } \\
\text { Cycle 2 (with drug) }\end{array}$ & $<0.001^{*}$ & $<0.001^{*}$ \\
\hline
\end{tabular}

Results are expressed as Mean \pm SD.

Paired ' $\mathrm{t}$ ' test was performed to compare between groups. $\mathrm{n}=$ Number of subjects; ${ }^{*}=$ Significant; $\mathrm{ns}=$ Not significant

Table-6 shows the side of the study respondents, 1(23.0\%) patients had gastrointestinal upset and $1(2.0 \%)$ patients had respiratory symptom in Group A and $1(2.0 \%)$ patient allergic reaction, $1(2.0 \%)$ visual symptom and respiratory distress were 2(4.0\%) cases in Group B.

Table VI: Side effects of Mefenamic Acid and Mefenamic Acid with Fennel group, (n=50)

\begin{tabular}{|l|c|c|}
\hline Symptoms & $\begin{array}{c}\text { Mefenamic } \\
\text { acid (n=50) }\end{array}$ & $\begin{array}{c}\text { Mefenamic acid } \\
\text { and fennel } \\
(\mathbf{n}=50)\end{array}$ \\
\hline Allergic reaction & 0 & $1(2.0 \%)$ \\
\hline Gastrointestinal upset & $1(2.0 \%)$ & 0 \\
\hline Visual symptom & 0 & $1(2.0 \%)$ \\
\hline Neurological symptom & 0 & 0 \\
\hline Respiratory distress & $1(2.0 \%)$ & $2(4.0 \%)$ \\
\hline
\end{tabular}

Group-A: Mefenamic acid

Group-B: Mefenamic acid with fennel

\section{DISCUSSION}

NSAIDS and HRT have significant side effects that are not popular with patients have limited effectiveness, or lack evidence of impacting the course of the disease. An increase interest in herbal and complementary medicine has led to a search for effective natural therapies that have significant effects in reducing pain intensity in primary dysmenorrhea.

NSAIDs, especially mefenamic acid, are the treatment of choice for dysmenorrhoea, showing $80 \%$ effectiveness. However, there is still a $20 \%-25 \%$ failure rate ${ }^{1,8}$, and side-effects such as diarrhoea and rashes ${ }^{9}$, immunohaemolytic anaemia ${ }^{10}$ and nephrotoxicity; overdose is accompanied by central nervous system toxicity and convulsions ${ }^{9}$. Herbal remedies may be a safer way to treat many common ailments including dysmenorrhoea. Fennel has been shown to be effective in the treatment of dysmenorrhea ${ }^{11}$. Although one report has suggested that fennel extract can stimulate uterine contractions and lead to abortion ${ }^{8}$, this claim has not been verified and is unlikely at treatment dose.

\section{Measurement of pain on VAS scale (1-10)}

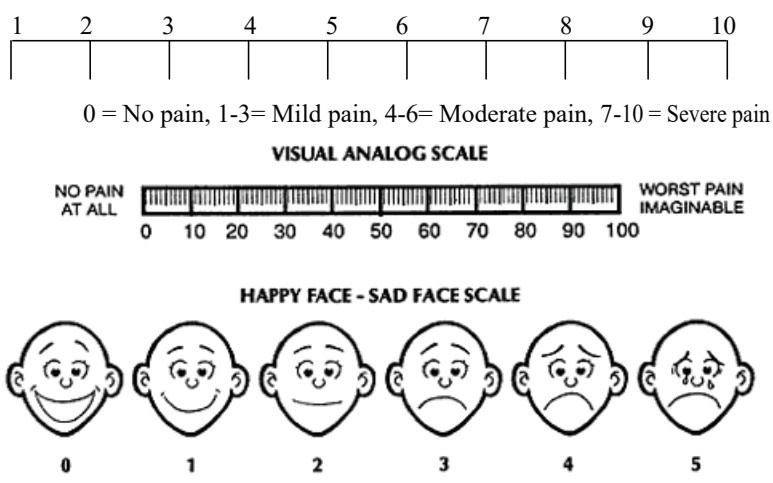

This study includes 100 students who suffered from dysmenorrhea. The mean of age (year) $21.60 \pm 2.59$, menarche age (year) 13.92 \pm 1.15 , duration of the menstrual cycle (day) 6.24 1.66 , duration of the cycle length (day) $27.36 \pm 3.63$, onset age of dysmenorrhoea (year) $16.16 \pm 1.81$, intensity of dysmenorrhoea (VAS) $6.5 \pm 1.6$ in Group A (Mefenamic acid) and mean age (year) $22.20 \pm 3.72$, Menarche age (year) $13.17 \pm 2.23$, Duration of the menstrual cycle (Day) 6.17 \pm 1.41 , Duration of the cycle length (Day) 27.03 \pm 3.81 , Onset age of Dysmenorrhoea (Year) 15.50 \pm 2.71 , Intensity of dysmenorrhoea (VAS) 6.6 \pm 1.4 in Group B (Mefenamic acid with fennel).

The age of menarche in this study was at least 11 years, and in Noroozi et al.'s study conducted in Bushehr in 2003, it was reported to be 9 years. The mean of pain intensity score in this study was $6.5 \pm 1.6$, which is in agreement with that reported by Iaghmaii et al.in Zahedan in $2005^{14}$. 
In the present study $73 \%$ of participants taking fennel extract recorded a decrease or complete absence of pain. The failure rate of NSAIDs is still $20 \%-25 \%$ study $^{1,8}$. In the present study about $20 \%$ of the mefenamic acid group reported moderate pain and $7 \%$ severe pain after treatment.

In the present study too, $80 \%$ of fennel-treated subjects had either pain decrease or pain relief after treatment and there was no significant difference in any of the dimensions of pain symptoms compared with the mefenamic acid-treated group. In the double-blind randomized study, it was demonstrated that Dill can be as effective as Mefenamic acid in decreasing the pain severity of primary dysmenorrhea. The results are in agreement with the results of Mohammadinia et al.

In present study, the findings of the pain intensity before and after drug in menses $1^{\text {st }}$ to $5^{\text {th }}$ day in Group B (Mefenamic acid with fennel). The mean intensity of pain in the mefenamic acid with fennel group decreased from $3.4 \pm 0.88,2.6 \pm 0.50,2.4 \pm 0.58,1.6 \pm 0.60$ and $0.6 \pm 0.59$ before drug down to $2.0 \pm 0.74,1.9 \pm 0.67,1.7 \pm 0.62$, $1.0 \pm 0.50$ and $0.2 \pm 0.70$ in after drug in the day of menstrual period, $1^{\text {st }}$ day, $2^{\text {nd }}$ day, $3^{\text {rd }}$ day, $4^{\text {th }}$ day and $5^{\text {th }}$ day respectively. The difference of pain intensity before and after use of drug were statistically significant. Nazarpoor $e t$ al. ${ }^{15}$ conducted a comparative study between Fennelin and Mefenamic acid in primary dysmenorrhea. Fennelin showed an effect similar to that of Mefenamic acid ${ }^{16}$.

In present study, the menstrual bleeding severity (cycles 0 , 1 and 2) in the two study groups, paired t-test used to compare bleeding and pain severity in the two groups. According to the results of the analysis, there was significant difference in bleeding severity in the Group A (Mefenamic acid) and Group B (Mefenamic acid with fennel) in zero to cycle 2 if menstrual bleeding. Fennel extract also decreased the intensity of pain, and the difference in the intensity of pain before and after the treatment was considerable. In a study on the effect of a combination of herbs (fennel, saffron and celery) on dysmenorrhea, the intensity of pain decreased from 5.3 to 3 in the second month and to 0.5 in the third month ${ }^{17}$.

According to the results of this study, a comparison of the groups treated with Mefenamic acid implies that the Mefenamic acid with Fennel groups prove to be more effective in pain relief than the Mefenamic, which is apparently connected with the potential pain relief mechanism it follows. The study results showed that both drugs were able to reduce pain during treatment. The effects of the Mefenamic acid was the same but higher than that of fennel.

\section{CONCLUSIONS}

The results of this study showed that taking Mefenamic acid with fennel can decrease the severity of dysmenorrhea. However, any intervention might be found out to treat dysmenorrhea with less adverse effects is highly desired. The effectiveness of herbal and medical treatments in dysmenorrhea is still under investigation and need more careful studies.

\section{RECOMMENDATION}

In this study the interactivity of fennel with other drugs were not explored especially with different NSAIDs and so also its effects on other signs and symptoms of primary dysmenorrhea.

\section{LIMITATION}

Therefore, it is recommended that further studies regarding pharmacokinetics, pharmacodynamics and toxicology of Foeniculum Vulgare should be undertaken to develop it as a useful analgesic agent for women.

\section{REFERENCES}

1. Speroff LE 2005. Clinical gynecologic endocrinology and infertility. 7th ed. Translated by: Ghazigahani B. Tehran: Golban Publication, p. 471.

2. Safari A, Shah Rezaei Gh, Damavandi A 2006. Comparison of the effects of vitamin $E$ and mefenamic acid on the severity of primary dysmenorrheal. J Army Univ Med Sci I.R. Iran, vol. 4, pp. 13 , pp. $735-8$

3. Hakiminia H 2005. A comparative study between mefenamic acid with mefenamic acid and vitamin $\mathrm{E}$ in release of pain in primary dysmenorrhea. Zahedan University of Medical Sciences, pp. 27-8. [MD Dissertation].

4. Bergner P 2001. Female herbs and dysmenorrhea. 2nd ed. Boa Raton: CRC, p: 53.

5. GlazkoAJ:Experimental observation of mefenamic acid partiii.Metabolic disposition of in fenamates in medicine.A symphosium.london1966.annals of physicalmedicine suppliment pp23-36'19676)

6. Unsal A, Ayranci U, Tozun M, Arslan G, Calik E 2010. Prevalence of dysmenorrheal and its effect on quality of life among a group of female university students. Ups J Med Sci, voll.115, no. 2, pp.138-45.

7. Modaress NV, Motamedi B, Asaddipour M 2006. Comparison between the pain- relief effect of fennel and mefenamic acid on primary dysmenorrhea. J Rafsanjan Univ Med Sci, vol. 1, no. 5, pp.1-6. 
8. Suhrabi Z, Tadayon M, Javadifar N 2006. Comparison of pressure effect on Sanyinjiao point with that of ibuprofen on primary dysmenorrhea. J Ilam Univ Med Sci, vol. 14, no. 2, pp. 30-5.

9. Mirzaee F, Bakhshi H, Yassini SM, Bashardust N 2003. The prevalence and intensity of primary dysmenorrhea based on personality type in Rafsanjan high school students. J Rafsanjan Univ Med Sci, vol. 2, no. 3-4, pp.151-7.

10. Berek JS 2007. Berek \& Novak's gynecology. Translated by: Ghazigahani B. 14th ed. Tehran: Golban Publication, pp. 484-5.

11. Doubova SV, Morales HR, Hernadez SF, et al. 2007. Effect of a Psidii guajavae folium extract in the treatment of primary dysmenorrhea: a randomized clinical trial. J Ethnopharmacol, vol.110, no. 2, pp. 305-10.

12. Noroozi A, Tahmasebi R 2004. Pattern of menstruation, hirsutism and dysmenorrhea in students of Boushehr medical and Khalig-e-Fars universities, 2002-03. Hormozgan Med J, vol. 7, no. 4, pp. 203-9.

13. Jahanian M, Rakhshandeh H, Teimuri M 1999. The effect of Chamomile extract on dysmenorrhea. Med J Mashad Univ Med Sci, vol. 42, no.64, pp. 33-40.

14. Torkzahrani Sh, Akhavan-Amjadi M, Mojab F, Alavi-Majd H 2007. Clinical effects of Foeniculum vulgare extract on primary dysmenorrhea. J Reprod Infertility, vol. 8. no. 1, pp. 45-51.

15. Nazar PS, Azimi H 2006. Comparison of fennel and mefenamic acid for the treatment of primary dysmenorrheal.J Mazand Univ Med Sci, vol.17, pp. 54-61.

16. Doll M 2009. The premenstrual syndrome: Effectiveness of Vitex agnus castus. Med Monatsschr Pharm, vol. 32, pp. 186-9

17. Khodakrami N, Moatar F, Ghahiri A, Solokian S 2008. The effect of an Iranian herbal drug on primary dysmenorrhea: A clinical controlled trial. JMWH, vol. 14, pp. 11-9.w 